\title{
VITAMIN A AND CAROTENE METABOLISM IN COWS AND THEIR CALVES FED FROM BUCKETS
}

\author{
J. BOUDA, P. JAGOŠ, VL. DVOŘ́K and V. HAMŠÍK \\ Department of Diagnostics, Therapy and Prophylaxis of Animal Diseases, University of Veterinary \\ Science, 61242 Brno
}

Received fanuary 26, 1979

\begin{abstract}
Bouda J., P. Jagoš, Vl. Dvořák, V. Hamšík: Vitamin $A$ and Carotene Metabolism in Cows and their Calves Fed from Buckets. Acta vet. Brno, 49, 1979: 45-52.

The vitamin A and carotene metabolism has been studied in $\mathbf{4 0}$ cows and their calves up to the age of three months under conditions of intensive production during winter season. The vitamin A level in blood plasma of pre-partum cows was found to be lower than that of post-partum cows. The vitamin A concentration in the first colostrum was 10 times higher than the concentration found in cow blood plasma. The carotene level in colostrum was lower than that in blood plasma of cows.

Before the first colostrum intake the average vitamin A concentration in blood plasma of calves was very low and did not exceed $10 \mu \mathrm{g} / 100 \mathrm{ml}$. After the colostrum ingestion the plasma vitamin A level raised, the hypovitaminosis A was, however, found in $75 \%$ of followed calves and in high number of calves continued up to the age of 3 weeks. In the following period the occurrence of hypovitaminosis in calves was reduced which was brought about by the addition of vitamin in milk substitute. The significant rise in plasma vitamin A levels occurred during the first weeks of calf life after vitamin A had been supplemented into the first colostrum. The carotene levels in blood plasma of calves up to the age of 8 weeks were very low and their increase appeared after the hay ingestion.

Under conditions of large-scale animal production the animals are concentrated in a small area and therefore the hypovitaminoses are accompanied by a potential danger of a disease affecting first of all the alimentary and respiratory tracts. It follows from our results that the addition of vitamin $A$ to calves in first days of their lives, especially in winter season, is of a great imporance.
\end{abstract}

Cow, calf, blood plasma, colostrum, vitamin A, carotene, metabolism.

Under normal conditions cattle do not ingest natural vitamin A but produce it from provitamins contained mostly in green food. Beta-carotene, converted mostly in the mucosa of small intestine to vitamin A, appears to be the most efficient provitamin. Calves are born with low levels and stores of vitamin $\mathrm{A}$ and carotene which indicates that the permeability of syndesmochorial placenta for these substances is considerably limited (Dann 1932).

Colostrum appears to be the only source of vitamin A and carotene in early postnatal period of calf life (Moore 1957; Steinbach, Meyer 1967; Steinbach et al. 1970; Branstetter et al. 1973; Tomlinson et al. 1976). The concentration of vitamin A and carotene in colostrum is influenced by the diet, season, breed and by individual differences. Steinbach and Meyer (1967) found in the first colostrum in winter season 1170 international units of vitamin $\mathrm{A} / 100 \mathrm{ml}$, in summer season 1890 I. U./100 ml. Similar values were reported by Branstetter et al. (1973),

The first results presented at the 2nd Symposium on Metabolic Disorders in High Yielding

Dairy Cows, Smolenice, June Ist, 1977 
although Sutton et al. (1947) obtained lower vitamin A concentrations. A significant rise in vitamin A level in colostrum appeared after several weeks of administration of $70000 \mathrm{I}$. U. of vitamin A (per day and cow) (Steinbach et al. 1970).

During the last weeks of pregnancy a decrease in vitamin A levels in blood plasma is very pronounced, this being probably due to the utilization of vitamin by dam organism in order to ensure an abundant intake of this substance of vital importance to a calf.

Vitamin A is necessary for animals to provide for normal growth, reproduction, normal function of epithelia, mucosae and for good health condition. Hypovitaminosis A may manifest itself by impaired growth, hyperkeratotic changes on skin and mucosae, by conjunctivitis, xerophtalmia, night blindness, diarrhea, by disturbances in bone growth and by function disorders of sexual organs, abortions, lower vitality and resistance of young animals towards respiratory and other infections (Moore 1957; Dvořák 1959; 1960; Přibyl 1963; Spratling et al. 1965; Mitchel 1967; Rosenberger 1970; Mingazov 1974; Jagoš et al. 1975). The increased susceptibility to diseases of alimentary and respiratory tract at hypovitaminosis follows from epithelization disorders and undoubtedly also from a limited activity of specific and non-specific defense mechanisms.

The determination of hypovitaminosis $\mathrm{A}$ on the basis of clinical signs is very complicated and for this reason the measurement of vitamin A, and possibly carotene concentrations in blood plasma, liver, colostrum and milk is well justified. Under normal corditions the vitamin A levels in blood plasma average about $30 \mu \mathrm{g} / 100 \mathrm{ml}$ in most animal species. Generally, plasma vitamin A concentrations below $10 \mu \mathrm{g} / 100 \mathrm{ml}$ are regarded as being very low, $10-19 \mu \mathrm{g} / 100 \mathrm{ml}$ as low and the range of $20-50 \mu \mathrm{g} / 100 \mathrm{ml}$ as reasonable (Sebrell, Harris 1967). In normal calves after colostral nutrition the vitamin A concentration in liver is $10-50 \mu \mathrm{g} / 1 \mathrm{~g}$ of tissue, in blood plasma over $25 \mu \mathrm{g} / 100 \mathrm{ml}$ (Rosenberger 1970). According to Repp and Watkins (1958) the vitamin A concentration does not drop below $25 \mu \mathrm{g} / 100 \mathrm{ml}$ in blood plasma, assuming that its reserve is sufficiently high.

Our worker Dvořák (1959) has studied vitamin A levels in calves in relation to maternal organism. In calves with restricted colostrum intake during first 15 days the vitamin A concentration in plasma decreased below $40 \mathrm{I}$. U./100 ml and at the same time $75 \%$ of calves was taken ill. Decreased vitamin A levels in blood plasma were found in all calves suffering from bronchopneumonia and in more than $50 \%$ of calves with dyspepsia (Dvořák 1960). In the case of beef cattle the weight gains were proved to be on a good level as long as the vitamin A concentration in blood plasma did not drop below $25 \mu \mathrm{g} / 100 \mathrm{ml}$ (Kohlmeier and Burroughs 1970). The vitamin A concentration decreasing under $15 \mu \mathrm{g} / 100 \mathrm{ml}$ in calf blood plasma, the lowered feed intake was observed (Abrams et al. 1969).

\section{Materials and Methods}

The study was carried out in winter season (January-April 1977) on 40 late-pregnant cows and their 42 calves of Czech Spotted breed in large-capacity cow-house accomodating 600 heads. The clinical examination and blood sampling was carried out $2-5$ weeks before the expected delivery and 2-4 weeks post partum on cows and from birth up to the age of 3 months on their calves. Apart from this, urine and average colostrum samples of the first milking were collected from cows. The nutrition (laboratory analysis of feed ration), zoohygienic conditions, the system of bucket feeding of calves, the level of care were followed. In the case of calves with diarrhoea the bacteriological examination of smears was carried out at the Research Institute of Veterinary Medicine in Brno.

Immediately after birth and navel stump treatment the calves were moved into individual cages and at the age of 14-18 days transferred to another calf-house, where they were placed also in cages till one month of age. Starting from the first colostrum ration the calves were fed from buckets twice a day. Daily colostrum ration was $4-5$ litres and from the sixth day the calves were changed to a milk substitute Laktosan A. On the 8th day calves were given 6-7 litres of Laktosan per head and day. The addition of a mixture TK-1 (concentrate) started from the 11th day and that of meadow hay from three we eks.

By clinical examination of late pregrant cows no significant changes were found whereas in most calves short-term diarrhoea at the age of 3-7 days was observed. In diarrhoea course no rise in body temperature was noted and in no case pathogenic serotype $E$. coli was found in bacteriological smears.

To diarrhoeic calves rehydrating solution in the amount of 6-8 literes was administered orally during 25 hours, exceptionally during 48 hours.

The average calf body mass before the colostrum intake was $42.2 \mathrm{~kg}$ and ranged from 36 to $56 \mathrm{~kg}$. Twins were not included in this range since their lowest mass reached $27 \mathrm{~kg}$ per one. The average daily gain up to three months of age was $0.52 \mathrm{~kg} / \mathrm{head}$. 
A half of newborn calves was given vitamin preparation Combinal $A+D_{2}$ supplemented to the first colostrum ration.

Calf blood samples were collected from v. jugularis prior to colostrum ingestion ( $1-4$ hours) and than after the colostrum ingestion after 1, 3, 7, 14, 21, 42, 56 and 84 days.

The vitamin A content in cattle blood plasma was determined on spectral Perkin-Elmer 204 fluorometer according to Thompson et al. (1971, 1973) using Van Stewenick, De Goeija (1973) information modified by Bouda and Jagoš (1979). The vitamin A content in colostrum was also determined spectrofluorometrically according to Senyk at al. (1975). The carotene level in blood plasma and colostrum was determined photometrically according to Knobloch (1956).

Obtained results were evaluated on a Hewlet-Packard computer, $9810 \mathrm{~A}$ Model. To test the difference significance of two selective means the Student's $t$-test was used. The method of simple split analysis and Duncan's test were used to evaluate the difference between the separate samplings.

\section{Results}

The vitamin and carotene levels in blood plasma of 40 cows and their colostrum are given in Table 1 . In pre-partum cows the vitamin A content was found to be significantly lower $(P<0,01)$ than in post partum cows. On the other hand, carotene was lowered in post partum cows. The colostrum from the first milking contained in average 10times higher amount of vitamin $\mathrm{A}$ in comparison with cow plasma.

The dynamics of mean plasma concentrations of vitamin A in calves in depen-

Table 1

The vitamin $A$ and carotene mean concentrations in blood plasma in prepartum and postpartum cows and in their colostrum

\begin{tabular}{|c|c|c|c|c|}
\hline Material & Followed index & Prepartum cows & Postpartum cows & $P$ \\
\hline Blood plasma & $\begin{array}{l}\text { vit. A }(\mu \mathrm{g} / 100 \mathrm{ml}) \\
\text { carot. }(\mu \mathrm{g} / 100 \mathrm{ml})\end{array}$ & $\begin{array}{r}43.4 \pm 5.7 \\
371.0 \pm 78.0\end{array}$ & $\begin{array}{c}48.2 \pm 8.0 \\
278.0 \pm 77.0\end{array}$ & $\begin{array}{l}+t \\
+t\end{array}$ \\
\hline Colostrum & $\begin{array}{l}\text { vit. A }(\mu \mathrm{g} / 100 \mathrm{ml}) \\
\text { carot. }(\mu \mathrm{g} / 100 \mathrm{ml})\end{array}$ & & $\begin{array}{l}440.0 \pm 334.0 \\
124.8 \pm 73.0\end{array}$ & \\
\hline
\end{tabular}

$P<0.01=++$

Table 2

The mean levels of vitamin $A(\mu \mathrm{g} / 100 \mathrm{ml})$ in blood plasma of 40 cows and their 42 calves

\begin{tabular}{|c|c|c|c|c|c|c|}
\hline \multirow{2}{*}{ Animal } & \multirow{2}{*}{$\begin{array}{l}\text { Age } \\
\text { (days) }\end{array}$} & \multicolumn{2}{|c|}{ Combinal $\mathrm{A}+\mathrm{D}_{2}$ added } & \multicolumn{2}{|c|}{$\underset{\text { added }}{\text { Combinal } A}+\mathrm{D}_{2}$ not } & \multirow{2}{*}{$P$} \\
\hline & & $\bar{x}$ & $s$ & $\bar{x}$ & $s$ & \\
\hline $\begin{array}{c}\text { Calves }(T) \\
T \\
T \\
T \\
T \\
T \\
T \\
T \\
T \\
\text { Cows }\end{array}$ & $\begin{array}{c}\text { Before colostrum intake } \\
1 \\
3 \\
5-7 \\
14 \\
21 \\
42 \\
56 \\
84 \\
\text { Prepartum }\end{array}$ & $\begin{array}{r}9.2 \\
29.4 \\
23.3 \\
21.1 \\
19.3 \\
19.4 \\
25.1 \\
28.7 \\
30.8 \\
-\end{array}$ & $\begin{array}{r}2.5 \\
10.8 \\
6.2 \\
5.1 \\
2.8 \\
3.2 \\
3.7 \\
8.7 \\
7.1 \\
-\end{array}$ & $\begin{array}{r}8.0 \\
15.5 \\
17.4 \\
16.6 \\
15.9 \\
19.3 \\
23.7 \\
26.1 \\
31.4 \\
43.3\end{array}$ & $\begin{array}{l}2.7 \\
4.2 \\
5.4 \\
5.3 \\
3.9 \\
3.7 \\
3.3 \\
9.9 \\
7.1 \\
5.7\end{array}$ & $\begin{array}{l}- \\
++ \\
++ \\
++ \\
++ \\
= \\
= \\
-\end{array}$ \\
\hline
\end{tabular}

$P<0.01=++$

$P>0.05=-$ 
dence on age is given in Table 2 . It is evident from the tables that the lowest values under $10 \mu \mathrm{g} / 100 \mathrm{ml}$ were found in calves before the colostrum intake but after the colostrum ingestion a significant rise was observed.

A marked increase in plasma vitamin A content in calves occurred after the addition of $15 \mathrm{ml}$ of Combinal $A+D_{2}$ into the first colostrum ration. Vitamin $A$ concentrations doubled after $24 \mathrm{hrs}$ when compared with a control group. Statistically significant differences outlasted 14 days after the addition of Combinal $\mathrm{A}+\mathrm{D}_{2}$. The vitamin A levels decreased under $20 \mu \mathrm{g} / 100 \mathrm{ml}$ in $75 \%$ of calves aged 3 days and in $85 \%$ of calves aged 7 days. After the 20th day of age the vitamin A increase was observed in both groups caused by vitamin A content in Laktosan. The carotene concentration in calf plasma increased markedly by the age of 8 weeks, i. e. when calves received hay in greater extent.

\section{Discussion}

The study of vitamin A and carotene metabolism represents only a partial compontent of experiments, the main objective being to elucidate the complexity of relations between a mother and her progeny in conditions of large scale production technology. The main task of this work was to study the vitamin A and carotene levels in blood plasma and colostrum of calves and their mothers and to utilize the obtained results in diagnostics and prophylaxis of most frequent calf diseases. So far no importance has been ascribed to metabolic disorders even though it is known that the factors, influencing metabolism, could often be important in etiology and pathogenesis of infectious diseases. From the aforementioned it follows that the work concerns even the problems of infectious diseases since the impaired metabolism could be a predisposing factor favourizing the growth of conditionally pathogenic germs, predominantly in gastrointestinal and respiratory tract.

The diagnostics of metabolic disorders in young animals in early postnatal period is rendered difficult due to a series of functional and morphologic changes that are, moreover, complicated in calves by a gradual development of forestomachs. The young animal's metabolism is influenced not only in the postnatal period; the manifestation of vital functions in first days of life is predisposed by mother metabolism from the prenatal period. From this reason our attention was firstly focused to the cow metabolism and to a system of preventive diagnostics, the part of which is formed by the so-called metabolic test.

Recently, several attempts have been made to apply the metabolic test to calves, too. Our observation shows that the metabolic test cannot be used for calves in the same extent as in cows. The choice of clinico-biochemical data for the diagnostics of metabolic disorders has to be carefully considered. It is necessary to take into account the development of immunobiological processes, the homeostasis lability and the change dynamics in dependence of age.

When evaluating nutrition of late-pregnant cows a slight excess of digestible nitrogen matter and shortage of starch units was found in cow Jud ration. Zoohygienic conditions and prophylactorium capacity were found to be unsufficient. Often and delayed colostrum feeding was one of the main defects, having quite a considerable effect on calf diarrhoea.

The vitamin A concentrations in blood plasma were found to be on a fair level although the carotene concentrations in plasma were lower which can be attributed to the parenteral application of vitamin A to cows six weeks prepartum. 
Significantly lower values of vitamin A observed in prepartum cows, in comparison with postpartum cows, have been in accordance with literature data (Thomps on and Mc Gillivary 1957; Gažo, Landau 1959; Samochin et al. 1975; Dvorák et al. 1978). The vitamin A decreases in plasma of prepartum cows are, according to Thompson (1975) probably caused by a vitamin A transfer to colostrum and not by hormonal changes as generally stated.

If we compare the vitamin A concentration in colostrum and blood plasma the significance of colostrum for the calf is more evident. The vitamin A concentrations in colostrum, as found by us, are in accordance with the results of Steinbach and Meyer (1967). Different results were observed in carotene levels which were found to be three times higher in cow blood plasma than in colostrum; however, according to literature data carotene is not transferred to vitamin $\mathrm{A}$ in the calf intestinal mucosa during the first weeks of their lives.

It follows from the observation of the vitamin A concentration in blood plasma of adult cattle and calves that calves are born with a very low level of vitamin A which is a result of a restricted transplacental transport from dam to foetus. The observed low concentration of vitamin A (about $10 \mu \mathrm{g} / 100 \mathrm{ml}$ ) in calf blood plasma before the colostrum intake is in agreement not only with our findings as far as calf foetuses are concerned (Jagoš et al. 1979) but also with data of other authors (Dvořák 1959). After 24 hours after the first colostrum ingestion a significant rise of vitamin A in calf plasma appeared, the vitamin A levels in control calves (without the vitamin $\mathrm{A}-$ Combinal $\mathrm{A}+\mathrm{D}_{2}$ addition) do not, however, reach normal values even after finished colostral nutrition.

It is evident from the results that in $75 \%$ of calves the plasma levels of vitamin A were reduced both at the age of 3 days and later. Only after the 20th day of age an increase in mean vitamin A levels appeared. This was ensured by vitamin A content in Laktosan. It cannot, however, be unequivocally stated that when administering Laktosan the hypovitaminoses in calves were not observed as found by Surynek et al. (1976). When determining the vitamin A content in milk substitute Laktosan the significant decrease, in comparison with a standard, of vitamin A was observed. In our experiment the reduced vitamin A values were found in $20 \%$ of calves aged 8 weeks. It seems, likely that the used method (Surynek et al. 1976) is not specific for vitamin A determination in plasma. This could explain the observed differences. Different amounts of vitamin A used in milk substitutes cannot also be excluded.

A marked rise in plasma vitamin A content in the first 14 days of calf life appeared when vitamins $\left(15 \mathrm{ml}\right.$ of Combinal $\left.A+D_{2}\right)$ were added to the first colostrum ration. It follows from our observation that colostrum is the only source of vitamin A in early postnatal period of calves and furthermore, it was demonstrated by us that in winter season even colostrum alone is not sufficient to provide vitamin A levels and that it is necessary to supply vitamin A in the first days of calf lives, the first colostrum ration being most suitable. Our observation is further supported by findings of Steinbach and Meyer (1967) who found the vitamin A content in colostrum being lower by $42 \%$ in winter than in summer.

Under conditions of large-scale rearing technology when animals are concentrated in small areas a potential danger of stress factors and diseases appears to affect first of all the alimentary and respiratory tract and to increase substantially organism demands on vitamins. A newly born calf has very low vitamin A stores and therefore its deficit or impaired availability result in an increased susceptibility to diseases not only as a consequence of epithelizing disturbances in pylorus, 
intestine and in respiratory tract but according to Elze et al. (1973) also lead to activity limitation of specific and nonspecific defense mechanisms.

The determination of hypovitaminosis on the basis of clinical signs is not easy. We suppose that the vitamin A level in blood plasma and its content in liver is a good indicator when determining hypovitaminosis $\mathrm{A}$ in calves. In the case of adult animals the vitamin A determination in liver is not always sufficient ( $\mathrm{T}$ ho $\mathrm{mp}$ son 1975) and complemental examination of blood plasma, and possibly of milk, is advisable. When vitamin $\mathrm{A}$ is not supplemented to animals the carotene determination in plasma is valuable.

\section{Metabolismus vitaminu A a karotenů u krav a jejich telat, napájených z nádob}

Metabolismus vitaminu A a karotenu byl studován v zimním období u $40 \mathrm{krav}$ a jejich telat do stáŕi 3 měsíců $\mathrm{v}$ podmínkách velkovýrobních technologií. U krav před porodem byla hladina vitaminu A v krevní plazmě nižší než po porodu. Koncentrace vitaminu A v prvém kolostru byla $10 \times$ vyšší než v krevní plazmě krav. Hladina karotenů byla v kolostru nižší než v krevní plazmě krav.

Před prŕijmem kolostra byla průměrná hladina vitaminu A v krevní plazmě telat velmi nízká a nepřesahovala $10 \mu \mathrm{g} / 100 \mathrm{ml}$. Po př́imu kolostra došlo ke zvýšení plazmatických hladin vitaminu $\mathrm{A}$, přesto však hypovitaminóza $\mathrm{A}$ byla zjištěna u $75 \%$ sledovaných telat a přetrvávala u vysokého počtu telat do stárí 3 týdnů. V dalším období došlo ke snížení výskytu hypovitaminózy u telat, což bylo způsobeno přidaným vitaminem $\mathrm{v}$ mléčné náhražce. $\mathrm{K}$ významnému zvýšení plazmatických hladin vitaminu A došlo $\mathrm{v}$ prvních týdnech života telat po přidání vitaminu A do prvního podaného kolostra. Hladiny karotenů v krevní plazmě telat do stáŕí 8 týdnů byly velmi nízké a $k$ jejich zvýšení došlo po př́ijmu sena.

V podminkách velkovýrobních technologií jsou zviŕata koncentrována na malém prostoru, a proto i při hypovitaminózách vzniká potenciální nebezpečí onemocnění, postihujících prredevším trávicí a respirační ústrojí. $Z$ našich výsledků vyplývá evidentní význam přidávání vitaminu A telatům $\mathrm{v}$ prvních dnech jejich života, zejména $\mathrm{v}$ zimním období.

Метаболизм витамина А и каротинов коров и их телят, поенных из сосудов

Метаболизм витамина $\mathrm{A}$ и каротина в зимний период изучался в кровяной плазме и молозиве 40 коров и в кровяной плазме их телят в возрасте до 3 месяцев в условиях промышленных технологий. У коров перед отелом уровень витамина А был ниже периода после отела. Концентрация витамина А в первом молозиве была 10 раз ниже кровяной плазмы коров. Уровень каротинов в молозиве был ниже кровяной плазмы коров.

До приема молозива средний уровень витамина $\mathrm{A}$ в кровяной плазме телят был очень низким - ниже мкг/100 мл. После приема молозива наблюдалось повышение уровня витамина А, однако гиповитаминоз А был выявлен в случае $75 \%$ исследуемых телят и имел место в большом количестве телят в возрасте до 3 недель. В последующий период произошло понижение наличия гиповитаминоза у телят, причина которого заключалась в добавлении витамина в молочном заменителе. Существенное повышение плазматического уровня витамина А произошло в первые недели жизни телят после добавления витамина А в первое подаваемое молозиво. Уровня каротинов в кровг- 
ной плазме телят в возрасте 8 недель были весьма низкими. Их повышение произошло после приема сена.

В условиях производственных технологий животные находятся на небольшом пространстве и в особенности при наличии гиповитаминоза существует возможная опасность заболевания, в первую очередь, пищеварительного и дыхательного трактов. Из полученных нами результатов вытекает существенное значение добавки витамина А телятам в первые дни их жизни, в особенности и в зимний период.

\section{References}

BOUDA, J. - JAGOŠ, P.: Stanovení vitaminu A a E v krevní plazmě, kolostru a játrech skotu. Vet. Med. (Praha), 1979, in press.

BRANSTETTER, R. F. - TUCKER, R. E. - MITCHELL, G. E. - BRADLEY, N. W.: Vitamin A transfer from cows to calves. Int. J. Vitam. Nutr. Res., 43, 1973: 142-146.

DANN, W. J.: Biochem. J., 26, 1932: 1072. Cit. DVOŘ́K, M., 1959.

DVOR̂́K, M.: Vitamin A a karoten $\mathrm{v}$ krevní plazmě sajících telat a jejich závislost na mateřském organismu. Sborník Vysoké školy zemědělské, B, Spisy veterinární fakulty (Brno), 7, 1959: 399-417.

DVORÁK, M.: Hypovitaminóza A u chorob sajících telat. Vet. Med. (Praha), 5, 1960: 521-536.

DVOŘÁ, M. - HERZIG, I. - VOJTÍŠEK, B. - TOULOVÁ, B.: Hladiny karoténu a fluorometricky stanoveného vitaminu A v krevní plazmě krav ve vztahu $k$ březosti a typu krmení. Vet. Med. (Praha), 23, 1978: 577-585.

ELZE, K. - MEYER, M. - STEINBACH, G.: Jungtierkrankheiten. Gustav Fischer Verlag, Jena 1973,130 pp.

GAŽO, M. - LANDAU, L.: Vitamin A vo výžive hospodárskych zvierat. SVPL, Bratislava $1959,115 \mathrm{pp}$.

JAGOS, P.: Skot - zdravotní problematika velkochovů. SZN, Praha 1975, 279 pp.

JAGOS, P. - BOUDA, J. - GERYK, J.: Hladiny vitaminů A, E a beta-karotenu u vysokobřezích krav a jejich fétů. Acta Vet. Brno, 48, 1979, in press.

KNOBLOCH, E.: Fyzikálně chemické metody stanovení vitaminů. ČSAV, Praha 1956, 459 pp.

KOHLMEIER, R. H. - BURROUGHS, W.: Estimation of critical plasma and liver vitamin A levels in feed lot cattle with observations upon influences of bcdy stores and daily dietary requirements. J. Anim. Sci., 30, 1970: 1012-1018.

MINGAZOV, T. A.: Rol' vitamina A v preduprežděnii embrionalnoj smertnosti. Životnovodstvo, 9, 1974: 68-69.

MITCHELL, G. E.: Vitamin A nutrition of ruminants. J. amer. vet. med. Ass., 151, 1967; 430-436.

MOORE, T.: Vitamin A. Elsevier, Amsterdam 1957, 645 pp.

PRIBYL, E.: Choroby mládat hospodářských zvírat. SZN, Praha 1963, 230 pp.

REPP, W. W. - WATKINS, W. E.: Carotene, vitamin A and inorganic phosphorus in the blood plasma of range cows. N. Mex. Agr. Exp. Sta. Bull., 1958: 420.

ROSSENBERGER, G.: Krankheiten des Rindes. P. Parey, Berlin, Hamburg, 1970, 1392 pp.

SAMOCHIN, V. T. - KUZNĚCOV, N. I. - SOLOVJEC, L. M.: Soděržanije vitaminov v krovi i moloke korov. Veterinarija, 9, 1975; 93-95.

SEBRELL, W. H. - HARRIS, R. S.: The vitamins (Chemistry, Physiology, Pathology, Methods). Academic Press, New York, London, 1, 1967: $570 \mathrm{pp}$.

SENYK, G. F. - GREGORY, J. F. - SHIPE, W. F.: Modified fluorometric determination of vitamin A in milk. J. Dairy Sci., 58, 1975: 558-560.

SPRATLING, F. R. - BRIDGE, P. S. - BARNETT, K. C. - PALMER, A. C.: Experimental hypovitaminosis - $\mathrm{A}$ in calves. Clinical and gross post - mortem findings. Vet. Rec., 77, 1965: $1532-1542$.

STEINBACH, G. - EIDNER, M. - MEYER, H.: Zur Auswirkung einer Vitamin-A-Zufütterung an tragende Muttertiere auf die Gesundheit der Kälber. Mh. Vet. Med., 25, 1970: 191- 195.

SURYNEK, J. - SLÁMOVÁ-ŠKOLOVÁ, Z. - JURKA, F.: Hladina beta-karotenu a vitaminu A v krevní plazmě telat $\mathrm{v}$ prvních čtyřech měsících postnatálního údobí. Vet. Med. (Praha), 21, 1976: 669-674.

SUTTON, T. S. - WARNER, R. G. - KAESER, H. E.: The concentration and output of carotenoid pigments, vitamin $A$ and riboflavin in the colostrum and milk of dairy cows. J. Dairy Sci., 30, 1947: 927. 
THOMPSON, J. N. - ERDODY, P. - BRIEN, R. - MURRAY, T. K.: Fluorometric determination of vitamin $A$ in human blood and liver. Biochem. Med., 5, 1971: 67-89.

THOMPSON, J. N. - ERDODY, P. - MAXWELL, W. B.: Simultaneous fluorometric determinations of vitamins $A$ and $E$ in human serum and plasma. Biochem. Med., 8, 1973: 403 too 414.

THOMPSON, S. Y. - McGILLIVARY, W. A.: Factors influencing the vitamin content of milk fat. V. Changes in vitamin A and carotenoids content of the blood plasma cows and heifers near parturition in relation to secretion of these substances in the milk fat. J. Dairy Res., 24, 1957: $108-114$.

THOMPSON, S. Y.: Role of carotene and vitamin A in animal feeding. World Rev. Nutr. Diet., 21, 1975: 224-280.

TOMLINSON, J. E. - HEMKEN, R. W. - MITCHEL, J. R. - TUCKER, R. E.: Mammary transfer of vitamin A alcohol and ester in lactating dairy cows. J. Dairy Sci., 59, 1976: 607-613.

Van STEVENINCK, J. - De GOEIJ, A. P. F. M.: Determination of vitamin A in blood plasma of patients with carotenaemia. Clin. Chim. Acta, 49, 1973: 61-64. 